UNIVERSITY OF CALIFORNIA PUBLICATIONS

AGRICULTURAL SCIENCES

Vol. 3 , No. 3 , 'pp. 37.54 , plate 12

September 29, 1917

\title{
SOME ABNORMAL WATER RELATIONS IN CITRUS TREES OF THE ARID SOUTH- WEST AND THEIR POSSIBLE SIGNIFICANCE
}

\author{
$\mathrm{BY}$ \\ ROBERT W. HODGSON \\ il
}

UNIVERSITY OF CALIFORNIA PRESS

BERKELEY

Cotry 2 


\section{UNIVERSITY OF OALIFORNLA PUBLIOATIONB}

Note.-Tbe University of Califomia Publications are offered in exchange for the publscatton of learned societies and institntions, universities and libraries. Complete lists of all the pnblicstions of the University will be sent npon request. For eample coples, lists of publications and other information, address the Manager of the University Press, Berkeley, Oallfornis, U. 8. A. All matter sent in exchange should bo addressed to The Fxchunge Department, Univergity Iibrary, Berkeley, Califormia, U. S. A.

AGRIOUITURAI SCIENCES,-Charles B. Itpman, Frnest B, Babcock, and John W. Gilmore, Bditors. Price per volume, \$5.

Vol. 1. 1. The Distribution and Activities of Bacterla in Solis of the Arid Reglon, by Charles B. Iipman. Pp. 1-21. October, 1812 .

2. Btndies on the Phenoldisulphonic Acld Method for Determining Nitrates in Soils, by C. B. Iipman and I. T. Sharp. Pp. 23-37. October, 1912.

8. The Effects of Calcium and Magnesium Carbonates on Bomo Biological Transformations of Nitrogen in Solls, by W. P. Kolley. Pp. 39-49. December, 1912

4. The Alnminum Reduction Meth od as Applied to the Determination of Nitrates in "Alkall" Solls, by Paul S. Burgess. Pp. 51-62. May, 1913

5. Studies Upon Influences Affecting the Protein Content of Wheat, by $G$. W. Shaw, Pp. 63-126. October, 1913

6. The Effect of Copper, Zinc, Iron and Lead Salts on Ammonlfication and Nitrification in Solls, by O. B. Iipman and P. S. Burgess. Pp. 127139. March, 1914

7. Studies on Ammonification in Solls by Pure Cultures, by C. B. Lipman and P. S. Burgess. Pp. 141-172, April, 1914

8. Humus and Humus-Nitrogen in California Soil Columns, by $\mathbf{B}$. $\mathbf{H}$. Loughriage. Pp. 173-274. August, 1914 .

9. Now Experiments on Alkali Soil Treatment (Preliminary Report), by Charles B. Iipman and Iuslie I. Sharp. Pp. 275-290, piates 1-4. June, 1915

10. Fundamental Interrelationships between Certain Solublo Salts and Soll Colloids, by I. T. Sharp. Po. 291-339. Aprll, 1916

11. Influence of the Composition and Concentration of the Nutrient Solution on Plants Grown in Sand Cultures, by Arthur Hugo Ayres. Pp. 341-394, pls. 5-15. January, 1917

12. Oertain Effects under Irrigation of Copper Compounds upon Crops, by

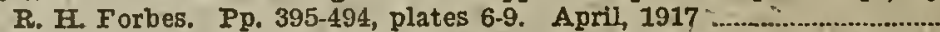

13. Experiments on the Effects of Constituents of Solid Smelter Wastes on Barley Growth in Pot Cultures, by C. B. Ilpman and W. F. Gerlcke. Pp. 495-587. March, 1917

Vol. 2. 1. Btudies in Juglans I. Study of a Now Form of Juglans . Californice Watson, by Irnest B. Babcock. Pp. 1.46, plates 1-12. Docember, 1913

2. Studies in Juglans II. Further Observations on a New Varlety of Juglans Californica Watson and on Certain Supposed Walnnt-Oaks Hybrids, by Ernest B. Babcock. Pp. 47-70, plates 18-19. October, 1914

3. Studies in Juglans, III: (1) Further Evidence that the Oak-like Walnut Originates by Mutation, by Emest B. Babcock. Pp. 71-80, pls. 20-21. September, 1916

Vol. 3. 1. Now Graśses for California, I, Phalaris stenoptera Hack., by P. B. Kennedy. Pp. 1-24, plates 1-8. July, 1917.

2. Optimum Moisture Conditions for Young Lemon Trees on a Ioam Soll by I. W. Fowler and C. B. Ispman. Pp. 25-36, plates 9-11. September, 1917

3. Some Abnormal Water Relations in Citrus Trees of the Arid Southwest and their Possible Significance, by Robert W. Hodgson. Pp. $37-54$, plate 12 . September, 1917

AGRIOULTURE.-The Publications of the Agricultural Experiment Station consist of Bulletins and Blennial Reports, edited by Professor Thomas Forsyth Funt, Director of the Station. These are sent gratis to citizens of the Btate of Califormia. For detalled Information regarding them address The Agrcultural Experiment Btation, Berkeley, California.

$$
\begin{aligned}
& \text { D. of D. } \\
& \text { oiit } 5 \text { is11 }
\end{aligned}
$$


UNIVERSITY OF CALIFORNIA PUBLICATIONS

IN

AGRICULTURAL SCIENCES

Vol. 3 , No. 3, pp. 37.54 , plate 12

September 29,1917

\section{SOME ABNORNAL WATER RELATIONS IN CTTRUS TREES OF THE ARID SOUTH- TIEST AND THEIR POSSIBLE SIGNIFICANCE}

BY

ROBERT W. HODGSON

\section{INTRODUCTION}

The progress of the development of the citrus industry, in general, and that of California in particnlar, has frequently been retarded or temporarily stopped by serious obstacles in the form of insect pests or plant diseases. Some of the most baffling of these tronbles fall naturally into a group which for want of a better name has come to be known as that of "physiological diseases," which are thought to be caused by various obseure derangements of nutrition or other vital functions. This group inchules mottled-leaf, die-back, chlorosis, June drop, puffing of the fruit, and other's of less importance. Knowledge of the true nature of this class of cliseases is extremely meager in spite of the fact that they have received much earnest attention from scientific investigators; and little can be accomplished in the way of devising control measures until much more is known in regard to them. Nor can we hope to progress far beyond the realm of speculation witlout greatly angmenting our knowledge of the physiology and anatomy of the normal citrus tree when grown under any one of a series of very widely varying environmental complexes which obtain in different parts of the arid sonthwest.

It is, therefore, proposed to attempt ly means of a series of syrstematic experimental studies to ohtain some definite and accurate information on the plyysiology of the genus ('itrus. It is hoped that the results may serve as a basis for the elucilation of some, at least, 
of the important problems referred to above. The studies in ruestion will attempt to shed light on transpiration problems, nutrition moblems, and others equally important. The paper which is submitted herewith forms an introductory eontribution to the subjeet under investigation.

The writer is not unaware of the essential similarity between the physiologieal problens presented by citrus and other fruit trees. He has ehosen, however, to study the physiology of the citrus tree as a separate entity because of the reasons given above, and the further one that the peculiar elimatic conditions under which this tree is frequently plaeed in the arid sonthwest, demand a speeial treatment. Doubtless mueh may be gained from these studies which will apply to physiological problems commected with other trees.

The data here presented were obtained dnring an investigation of one of the so-called physiologieal diseases above mentioned, namely, the June drop. ${ }^{2}$ Ever since the Washington Navel orange has been grown in the dry interior valleys of Arizona and California, this variety has been subject to excessive dropping of the young funits. This has came to be known popularly as the June drop although the fall of the fruits is by no means confined to June but may oceur at any time from petal fall, in April, until the fruit reaches several inches in diameter in August. The prevalence and amount of this dropping seems to be influenced to a narked degree by eertain environmental factors to whieh the trees are subjeet. The regular anumal shedding of the young fonits is most serious in regions where the ammal precipitation is lowest, the mean summer temperature highest, atmospherie lumiclity lowest, solar radiation most intense, and air movement greatest during the growing season. That the exeessive drop of young fruit is in some way intimately comnected with extreme elimatic eonditions is indieated by the fact that in some parts of sonthern California, where the drop is ordinarily not excessive, the lot wave of June 15-17, 1917, during which a temperature of $118^{\circ} \mathrm{F}$ was experienced in the Riverside and Redlands districts. was immediately followed by a drop so severe that practically the entire young erop of navel oranges was lost.

The experimental work from whieh the data were obtained was earried on at Edison, Kern County, California. Edison eomprises

1 This investigation, which is now in progress, was carrier on in collaboration with Professor J. Eliot Coit who plannel the first series of experiments and began the work in February, 1916. A joint-autholship laper correlating this and other aspects of the June trop phenomenon is in course of preparntion. 
a small colony of about seven hundred acres of orange orehard loeaterl eight miles sontheast of Bakrrsfielel and surromeled on two sides by typical desert of the southern San Joaquin valley, with its charaeteristic semixerophytic flora. Extreme elmatic conditions, as above mentioned, are operative there but the Washington Nave? orange matures early and is of excellent quality, although crops are small beeanse the drop referred to is excessive.

\section{Witer Relltions and Abscission}

It has long been recognized that abnormalities or irregularities in the water relations of plants are often associated with the abseission of rarious plant parts. Balls ${ }^{2}$ was able to cause complete shedding of leaves, flower buds, and bolls of the cotton plant Gossypium herbacrum within four days by pruning the roots and so limiting the ability of the plant to take up water. Lloy ${ }^{3}$ in his investigation of the eause of abscission in the same plant came to the conchusion that the cansative factor lay in a steady deerease in the moistmre content of the soil in contact with the roots of the plant. This realuction canses a severe tax on the power of the plant to maintain normal water relations and results in fluctuations in the water content of the gerial parts which, in turn, hads to abscission.

Althongh the work of Lloyd was performed in the humid sonthern states, he makes the statement that "there seldom ocenrs a day on which there is no minus water flutuation in the plant." He basel this conclusion not only on data derived from sherkling records but also on a study of transpiration rates, and water deficit in the leaves. In connection with his observations on the effect of temperature in causing acceler"ation of abscission, he eame to the conclusion that "the water elefieit is the cause of the rise of temperature in the tissues and that this constitutes the stimulus which direetly leads to abscission."

Other evidenes of the oenryener of markex deficits in the water content of plant organs is not lacking. Livingston and Brown, ${ }^{+}$working with a number of plants growing near Tuseon, Arizona, found that (with the exeption of the true xeroplyytes as Coviller and Prosnpis) thring the afternoon the leaves sufferen a marked deerease in water eontrut which was made up during the night. This periorice

2 Cairo Sc.i. Jour., vol. 5, r. 221, 1211.

3 Trans. Royal Sor. Can., ser. 3, vo1. 10, I. 55, 1916, see also Bull. Torr. Bot. Club, vol. 40, 1). 1-26, Jan., 1913.

4 Bot. Gaz. vol, 53, 1. 319, Ap̣ril, 1912. 
dinrnal condition of dessication has been found by Livingston and Brown to serve as a check on the absolute transpiration and has been termed "incipient drying." Lloyds independently obtained similar results in his investigations on Fouquieria splendens and Mrs. Shreve" established the same phenomonon in 1913 with Parkinsonia mierophylla.

Inasmuch as the genus Citrus is undoubtedly a mesophyte of tropical origin and therefore grown in the interior valleys of California under purely artificial conditions, ${ }^{7}$ it would naturally be expected that the abnormal water relations above discussed might obtain to an musual degree, especially during the hot growing period, when the ability of the plant to make up for excessive transpiration is taxed to the limit. Citrus fruits are borne on wool of the current season's growth which ordinarily bear's six to eight leaves on the same fruiting shoot. Therefore, it seemed reasonable that under conditions of exeessive transpiration the leaves might draw on the water supply of the fruits and thus bring about an abnormal water relation. With the above considerations in mind it occurred to the writer that this premature fall of the fruits might be due to iregularities or abnormalities in the water relations between the fruits and foliage, resulting in abscission in some way analagons to the shedding of cotton bolls under the stimulus of a water deficit.

The method used in obtaining the data here presented consisted in the main of simple moisture determinations of leaves and fruts of various kinds taken at different hours of the day. The material was gathered and quickly placed in weighing cups fitted with ground glass covers. After weighing, the material was thoronghly dried and then reweighed. For convenience in the case of fruits and large leaves, the material was ent into small pieces. The ealculations are based on the dry weight of the material, exeept as otherwise stated. The data obtained are shown in eondensed form in table 1. The figures shown represent averages of at least ten duplieate determinations, and in most instances of more.

The data presented in table 1 show some very interesting conditions. It is quite elear that, with the exeeption of the new succulent growth, the young fruits are at all times ligher in water content than the leaves situated near them. These data also seem to leave no doubt

\footnotetext{
5 Plant World, vol. 15, p. 11, 1912.

6 Ann. Rpt. Dir. Bot. Res. C. I. W., Feb. 12, 1913, p. 81.

i For a more complete discussion see Livingston, B. E., "A single index to represent both moisture ani temperature coulitions as relatei to plants." Pliysiological liescarches, vol. I, No. 9, April, 1916.
} 
TABLE 1

Average Molsture Content

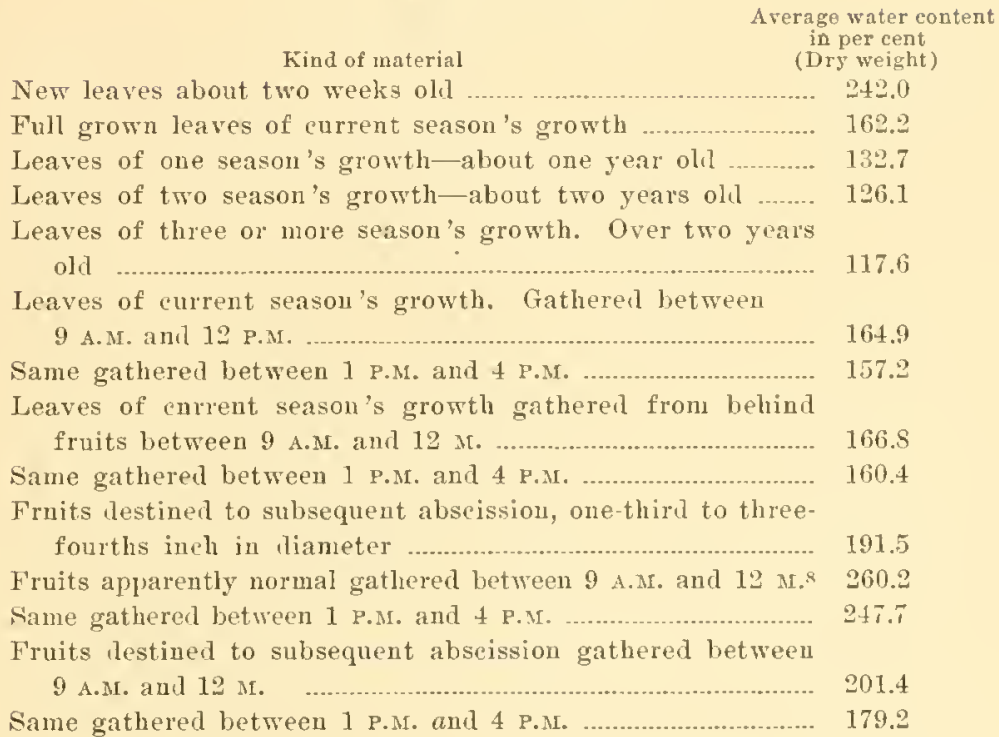

of the fact that as the leaves grow older there is a progressive deerease in water content.

It is also quite evident that a regular dimmal deerease in the water content of leaves of the current season's growth is manifest during the afternoon. Sueh leaves averaged $\mathbf{1 6 4 . 9 \%}$ in water eontent for the period between 9 A.r. and 12 m. and only $157.2 \%$ for the period between 1 P.M. and 4 P.M. This differenee does not appear signifieant when riewed in the light of the large differences obtained by Livingston and Brown with some of their material. However, it should be borne in mind that those anthors were dealing, for the most part, with mueh more sueenlent plants containing a large amount of water storage tisswe. Further, it should be noted that these figures are averages, since the determinations on which they are basest were not made at the same hours. Individual pairs of determinations frequently showed differences of as mueh as $25 \%$ to $30 \%$ in as short a period as six hours. On June 5 at $2: 30$ P.M., with the temperature at $95^{\circ} \mathrm{F}$ and the relative hmmidity at $19 \%$, the water eontent of leaves of the eurrent season's growth was $144.3 \%$. At 4 A.M. the next morn-

8 The fruits used for these determinations averaged a little larger than those gathered in the forenoon and therefore would normally be somewhat higher in water eontent. 
ing, with the temperature at $62^{\circ} \mathrm{F}$. and the humidity $54 \%$, the water content of similar leaves was found to be $172.6 \%$, showing a difference of $28.3 \%$. This phenomenon is taken to indicate the presence of ineipient drying in eitrus and is in full aeeord with the results of the writers above mentioned as well as with those obtaind by Lloyd.

Since the young froits lave a higluel water content than adjoining leaves which, in turn, exhibit a dimmal decrease in retative water content, the conelusion, "primi, that the haves might possibly draw on the watel supply of the fruit during periods of excessive transpiration seemed entirely plansible. If such is the case it would seem that leaves so favorably situated should not show this daily variation, at least to the degree shown in the leaves not so farorably sitnated. The data in table 1 show, however, that the average difference in water content of the two sorts of leaves gathered in the forenoon and afternoon is quite small. This is taken to indicate that if such leaves do utilize the water supply of the frnits. the evaporating power of the atmosphere is so strong that as fast as they receive this surplus water, it is lost and thus causes no appreciable difference in their relative water content.

The next step was to ascertain the watre content of different kinds of fruits, those destined to lemain and mature, and those showing indieations of subsequent abseission. Tt is quite casy to distinguish between the two, from a week to ten days before abscission occurs, by the difference in their appearance. Exposed fruits destined to drop exhibit a small yellow spot alout the navel end several weeks before the actual drop ocenrs. This spot gradually extends and spreads until at abscission it usually oempies at least half the area of the fruit. In the ease of well-shated fouits, the yellow eolor is eventy distributed over the entire surface. A large number of moisture doterminations were male which showed that those fruits destined to sulsequent alsscission averaget $59 \%$ less water than those fruits destined to remain and mature. (See table 1.) The presence of this condition in the fruits, espectally when consiclered in comnection with the daily increase at certain hours in the water deficit of the leaves immediately behind them, seems to point to the possibility of the leaves depriving the fruit of a part of their normal water supply. It certainly indicates an abnormal water relation.

Lemon growers prme their trees at all seasons of the year, even while the fruit is still on the trees. It is a well established practice to gather the good fruit from the exeisod branches immediately, in order to prevent it from beconing flaceid. Tnasmueh as the fruit, as ordi- 
narily picker from the tree, remains turgid for several months, it is the eommon belief that the leaves draw the water ont of the frnit when the branch is severed from the tree. That this is exactly what does ocenr, when the leaves are deprived of their normal water supply, is shown by the following experiments:

Erporiment 1 - Two shoots hearing small teroninal oranges of approximately the same size and having the same number of leaves aurl approximately the same leaf area, wee taken to the Iaboratory, placed on the table and allowed to dry under similar conditions except that in one tase the fruit was severed from the stem. All cut surfaces were sealed with vaseline.

Within twelve hours a marked difference in appearance was ohserved. The leaves on the shoot from which the orange was detached were considerably shriveled while those on the other shoot remained turgis and fresh. This difference beame more prononnced as time elapsed and in thirty homs a distinct difference in the appearance of the fruits as well as leaves was visible. The Ietached frnit remained firm and retained its dark green color ant lustre while the attached fruit was soft and flaceid and pxhibited a dull green color without Instre. This experiment was performed reperitedy with both oranges and limons with the same results. (Sree plate 12, fig. 1.)

As all the cut surfaces were sealed, it seems clear that the leaves on the shoot with fruit attaelued actually drew on its water content and that it was this supply of water which enabled them to remain alive and fresh long aftur the leaves on the other shoot liad withered and dietl.

Expcriment 2-Quantitative data on water content were desired to substantiate the visible inclieations deseribed in Expreiment 1. Therefore the latter was repeated several times and moisture determinations on leaves and fruits were made at various periods. A representative set of such determinations is given in table 2 :

TABLE 2

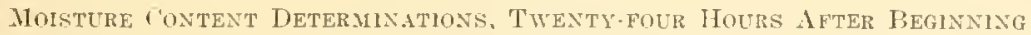

\begin{tabular}{|c|c|c|c|c|}
\hline \multirow[b]{2}{*}{ Kind of material } & \multicolumn{4}{|c|}{ OF EXPERIMENT "2 } \\
\hline & $\begin{array}{l}\text { Weight of } \\
\text { container and } \\
\text { fresh material } \\
\text { jn grams }\end{array}$ & $\begin{array}{l}\text { Weight of } \\
\text { same when } \\
\text { dry }\end{array}$ & $\begin{array}{l}\text { Wright of } \\
\text { material in } \\
\text { griams }\end{array}$ & $\begin{array}{l}\text { Watercon. } \\
\text { tent per } \\
\text { cent }\end{array}$ \\
\hline tarlied from branch. & ... 23.40 & 21.670 & 2.665 & 155.0 \\
\hline ached to branch. & 23.585 & 22.367 & 2.075 & 142.1 \\
\hline branelı & $\int 21.831$ & 21.805 & .181 & \\
\hline removerl & $\{22.045$ & 22.010 & .170 & $21.4 \mathrm{avg}$. \\
\hline (b) & $\int 21.345$ & 21.275 & .175 & .......... \\
\hline ttached & 20.604 & 20.477 & .254 & $73.7 \mathrm{avg.}$ \\
\hline
\end{tabular}


These data show that after twenty-four hours the leaves on the shoot with orange attached contained an average of $52.3 \%$ more water than those on the other shoot. They further show that the detached fruit contained $42.9 \%$ more water than the attached fruit from which the leaves had been drawing their supply. This is considered to be eonchusive evidence that in the case of excised branches the leaves ean draw water from the fruit.

Experiment 3-Two shoots in every respect similar to those used in the previous experiments were treated in the same manner as those of Experiment 1 and 2. These were then weighed at irregular intervals until they had reached a eonstant weight. During the interim they were kept on the laboratory table. 'The data obtained are found summarized in table 3 :

\section{TABLE 3}

Water rontent Determinations Made at Irregular Intervals Based on THE WHOLE WeIght

Shoot with orange attached

Shoot with orange detached

\begin{tabular}{|c|c|c|c|c|c|c|c|c|}
\hline $\begin{array}{l}\text { Number } \\
\text { of hours } \\
\text { elapsed }\end{array}$ & $\begin{array}{l}\text { Weight } \\
\text { in grams }\end{array}$ & $\begin{array}{l}\text { Loss in } \\
\text { grams }\end{array}$ & $\begin{array}{l}\text { Loss in } \\
\text { per cent }\end{array}$ & $\begin{array}{c}\text { Difference } \\
\text { in } \\
\text { per cent }\end{array}$ & $\begin{array}{l}\text { Weight } \\
\text { in grams }\end{array}$ & $\begin{array}{l}\text { Loss in } \\
\text { in grams }\end{array}$ & $\begin{array}{l}\text { Loss int } \\
\text { per cent }\end{array}$ & $\begin{array}{l}\text { Difference } \\
\text { in } \\
\text { per cent }\end{array}$ \\
\hline 0 & 4.872 & ....... & ....... & $\ldots$ & 4.777 & ......... & ....... & -..- \\
\hline 3 & 4.436 & .436 & 8.9 & .6 & 4.380 & .397 & 8.3 & $\ldots$. \\
\hline 19 & 3.957 & .915 & 18.7 & $\ldots$ & 3.830 & .947 & 19.8 & 1.1 \\
\hline 21 & 3.895 & .977 & 20.0 & -..- & 3.742 & 1.035 & 21.7 & 1.7 \\
\hline 24 & 3.803 & 1.069 & 21.9 & ... & 3.607 & 1.170 & 24.4 & 2.5 \\
\hline 26 & 3.683 & 1.189 & 24.4 & .... & 3.442 & 1.385 & 27.9 & 3.5 \\
\hline 27 & 3.610 & 1.262 & 25.9 & ...- & 3.342 & 1.435 & 30.0 & 4.1 \\
\hline 44 & 3.263 & 1.609 & 33.0 & $\ldots$. & 2.911 & 1.566 & 39.1 & 6.0 \\
\hline+9 & 3.047 & 1.825 & 37.4 & $\ldots$. & 2.682 & 2.095 & 34.8 & 6.1 \\
\hline 51 & 2.920 & 1.952 & \pm 0.0 & .... & 2.575 & 2.202 & 36.0 & 6.0 \\
\hline 91 & 2.125 & $2.7+7$ & 56.3 & .... & 2.005 & 2.769 & 57.9 & 1.6 \\
\hline 96 & 2.053 & 2.819 & 57.8 & ... & 1.960 & 2.817 & 58.9 & 1.1 \\
\hline 99 & 2.000 & 2.872 & 58.9 & .... & 1.935 & 2.842 & 59.5 & .6 \\
\hline 116 & 1.921 & 2.951 & 60.5 & .... & 1.873 & 2.904 & 60.8 & .3 \\
\hline 119 & 1.894 & 2.978 & 61.1 & ... & 1.852 & 2.925 & 61.2 & .1 \\
\hline 121 & 1.881 & 2.091 & 61.3 & $\ldots$ & 1.844 & 2.933 & 61.4 & .1 \\
\hline $1 \pm 0$ & 1.825 & 3.041 & 62.5 & .4 & 1.807 & 2.970 & 62.1 & $\ldots$ \\
\hline 146 & 1.797 & 3.075 & 63.1 & .5 & 1.783 & 2.994 & 62.6 & $\ldots$ \\
\hline 162 & 1.774 & 3.098 & 63.5 & .6 & 1.770 & 3.007 & 62.9 & $\ldots$ \\
\hline 186 & 1.736 & 3.136 & 64.3 & .8 & 1.743 & 3.034 & 63.5 & $\ldots$ \\
\hline 195 & 1.717 & 3.155 & $6 \pm .7$ & .9 & 1.726 & 3.051 & 63.8 & $\ldots$. \\
\hline 211 & 1.705 & 3.167 & 65.0 & 1.1 & 1.720 & 3.057 & 63.9 & $\ldots$. \\
\hline 218 & 1.695 & 3.177 & 65.2 & 1.0 & 1.710 & 3.067 & 64.2 & $\ldots$. \\
\hline 260 & 1.666 & 3.206 & 65.8 & 1.1 & 1.686 & 3.091 & $6 \pm .7$ & $\ldots$. \\
\hline 255 & 1.652 & 3.220 & 66.0 & 1.1 & 1.675 & 3.102 & 64.9 & $\ldots$ \\
\hline 306 & $1.6 \pm 3$ & 3.230 & 66.2 & 1.1 & $1.66 \pm$ & 3.113 & 65.1 & $\ldots$. \\
\hline 330 & 1.631 & $3.2 \pm 1$ & 66.5 & 1.1 & 1.652 & 3.125 & 65.4 & $\ldots$. \\
\hline 525 & 1.613 & 3.259 & 66.8 & 1.0 & 1.631 & 3.146 & 65.8 & $\ldots$. \\
\hline
\end{tabular}


The data in this table indicate that the amount of water in the fruit available for use by the leaves was suffieient to maintain the latter alive for approximately 50 hours after the shoot was ent from the tree. It is further evident that when three hours had passed the leaves on the shoot with fruit attached had not yet begm to take water from the fruit to any appreciable extent becanse the shoot with fruit detached shows less water loss than the shoot with fruit attached. However, this conclition was soon reversed and the leaves began to

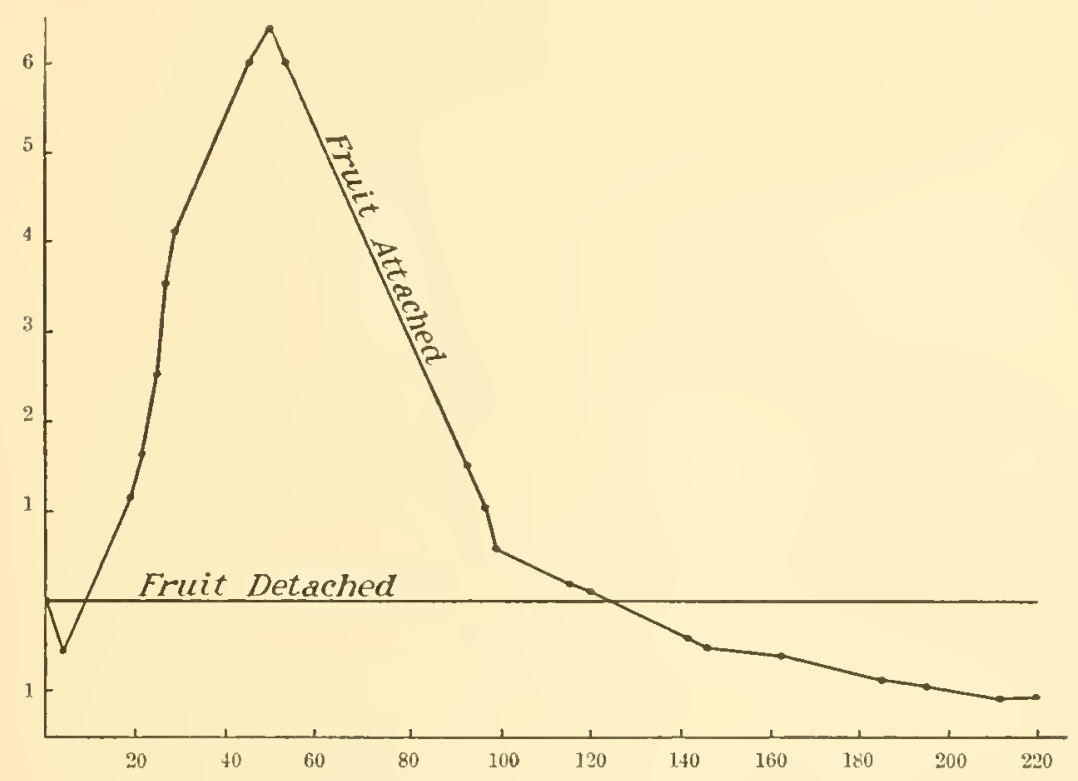

Fig. 1. Showing the difference in per cent of water loss of shoot with orange attached and shoot with orange detached. The water loss curve of the shoot with fruit detached is considered as normal. Ordinates represent differences in per cent of water loss, abscissae, the time elapsed in hours. Water content calculated on basis of fresh weight.

draw on the water in the fruit while the leaves to which no water was available from the fruit showed indieations of wilting.

That shortly after 50 hours had passed death ocenred in the leaves of the shoot with fruit attached is shom by the rapid increase in the amount of water loss. This was mudoubtedly the to increased permeability of the eytoplasmie cell membranes after death. After 50 hours the difference in water content of the two was $18.3 \%$ in favor of the shoot with fruit attached. However, from this time on until both had reached a constant rate of water loss (after abont 200 
hours), this shoot lost water more rapicly than the shoot with fruit detaehed. These relations are very clearly shown in figure 1. The normal water loss curve is ilhstrated in fignre 2.

Experiment $1-\mathrm{A}$ forked twig bearing a small terminal fruit on each branch was selected and cut. The fruits were immediately immersed in water and the shoot tied to a support in such a fashion that all the leaves were exposed to the air, the fruits alone being immersed. One orange was now removed by eutting it under water and all ent surfaces were sealer. The two fruits remained under

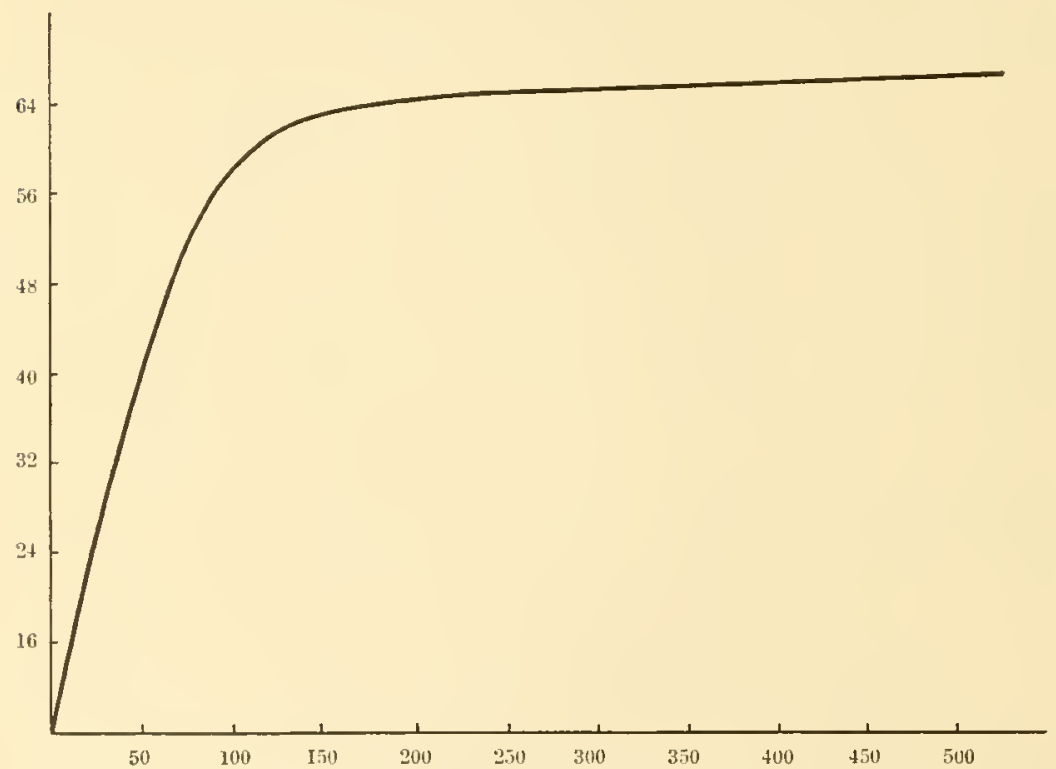

Fig. 2. Showing the general type of water loss curve of a shoot letacheil from the tree, inchuding letarhed orange. Orilinates refresent water loss in per cent anil abseissae, the time elapsed in hours.

water. The container and support were the'n placed on a bench in the shade in the open air and left for fifteen hours, at the end of which time moistme determinations were made on the fruits.

\section{TABLE 4}

Moisture Deterninations AFter Fimpen hlouts

\begin{tabular}{|c|c|c|c|c|}
\hline Kind of material & $\begin{array}{l}\text { Weight of } \\
\text { container ind } \\
\text { fresh material } \\
\text { in gralus }\end{array}$ & $\begin{array}{l}\text { Weight of } \\
\text { same when } \\
\text { dry in } \\
\text { grans }\end{array}$ & $\begin{array}{l}\text { Wright of } \\
\text { material in } \\
\text { grams }\end{array}$ & $\begin{array}{l}\text { Water con. } \\
\text { tent per } \\
\text { cent }\end{array}$ \\
\hline Detacher orange & $\ldots 24.680$ & 21.435 & 8.330 & 206.9 \\
\hline Attacherl orange & ... 23.210 & 21.773 & 2.570 & 126.8 \\
\hline
\end{tabular}


The data in table $t$ show that at the ent of fifteen hours there was a difference in water content between the two fruits of $80.1 \%$. There seems to be no way of accounting for this large difference other than that the leaves had aetually drawn the major part of it at least, from the attached fruit.

\section{W.ater Trinsiont śtudes by Mleans of Dye śtuff Solutions}

Erperiment j-Bearing the foregoing findings in mind, it seemed desirable to determine something of the natmre of this revisal of normal water flow by means of dye solutions. Accordingly a shoot bearing a terminal fruit was ent from the tree and the orange pared away at the apieal end to open the tracheal elements and admit the dye." This paring was done muder the solution to prevent the entrance of air bubbles. Water soluble eosin was used. The orange was inmersed in the liquid for a half hour, after which the shoot was sphit open. The traeheal tubes throughout all parts of the leaves, stems and fruits were found to be strongly stained.

Experiment ti-lt seemed desirable to simulate the actual situation on the tree as nearly as possible and the following experiment was designed to accomplish this. A crooked fruiting branch bearing a number of small lateral shoots and leares, and one terminal orange was cut under water. The ent end was kept under water and the branch so supported that the fruit was immersed in an eosin solution. The apex of the orange was then pared as deseribed above. The branch then rested with its basal end in water and the vasenlar bundles of the fruit open to eosin at the other end of the branch. (Sec pl. 12, fig. '2.) If we substitute for the water contain' the conducting system of the tree, and for the watery solution of eosin the developing fruit high in water eontent, we have very similar eonditions to those existing in the experiment, save for the fact that the fruit is not open to the air and the conducting system bears a celtain lelation to the rest of the tree.

The experiment was begun late in the afternoon and the branch left outdoors over night. At 8 o elock the next morning the leaves were examined and found to be very fresh and turgid. Indered they were noticeably much fresher in appeasance than they harl been the evening before. On eareful examination absolntely no trace of eosin

9 It should be stated here that the Washington Navel orange is in realitr a double frnit, with a smałl secondary orange within a large primary fruit. This interiol fruit constitutes what is known as the navel and it possesses an indepenclent vascular system of its own which traverses the central jith of the primary fruit hefore ramifying through the secondary orange. This central pith thus acts as the stem to the small fruit. 
ing between 50-100 per square millimeter as compared to $300-450$ per square millimeter on the leaves. Heasurements of the leaves situated within six inches of the fruit showed that, in addition the leaf area immerliately behind the young growing fruit is larger than the area of the fruit until it reaches approximately two inches in diameter, after which falling of the fruit is comparatively rare. Therefore, it seems highly probable that the transuriration of the fruit as compared to that of the leaves situated immediately behind it is an ahmost negligible factor and it appears reasomably certain that either water is actually draw back or that the normal supply is decreased.

Considering these two possibilities, the first merits more consideration as it is supported by proof which, though not absolute, is at least presumptive evidence of a strong enongh character; while on the other hamd the second possibility, agreeing though it does with the most recent theory on salp movements in plants as put forth by Dixon, is still a theoretical consideration. Aceording to this theory, which postulates strong tensions existing in the ascending water columns, no assumption of an actual reversal of the enrent is necessary in orcher to explain a decrease in moisture eontent. During normal conditions the relation between the tensions existing in the water columns leating to the fruits and those leathing to the leaves is such that both organs receive an aternate water supply. The tension existing in any one of these water columns is a function of the transpiring force existing in the transpiring plant organ as modified by atmospheric conditions. Therefore, as these transpiring forces vary, the tensions vary. Transpiration from the leaves, for reasons pointed out above, is subject to mnch greater variation than that from the fruits. Therefore during periok when evaporation is greatly accelerated the tensions in those water columns leading to the leaves are greaty increased and as a consequence more water is drawn to them. As the sonce of supply in the conclueting system is practically constant, the amount in the fruits is thereby reduced and this results in a decrease of relative water content of a magnitude contitioned hy the transpriration of the fruit.

However, it should be noted that the data in table 1 show a deerease in absolnte water content of the fruit of $15 \%$ to $20 \%$, a loss of eonsiderable magnitude. There are only two ways in which sueh a decrease in absolnte water content can take place: (1) the water is lost by transpiration from the fruit, or (2) it is drawn back by the leaves. But since the fruit possesses a very small stomatal area 
as compared with the leaves and, morrover, it is highly probals]e that a large percentage of this area is non-functional, being obstrueted by arecumulations of a resinous nature, there is small like ihood for absolute loss of watu in this manner to the extent noted. Hence there seems but one way to explain it and that is ly movement backs from the finuits.

Evidence of an indinecet nature pointing to the same conelnsion lies in the fact that there are some indications that ahscission of a certain proportion of the young firuits is directly the to the influener of hydrolysing enzymes secreted by certain saprophytic or faenltative parasitie fungi always found present on the shriveled style and frequently in the proliferations of the navel. Such enzymes in order to act on the alsseission layer must be drawn back through the vasenlar systrms of the fruit into the perlicel where this layer is locaterl. Investigations on this point ar now in progress.

Exprriment $\gamma$-Three similar fruits were sulected on different parts of a tree; on one of the lower branches in the sharle, at a height of four feet, and in the top of the tree in full sumlight. At noon each fruit was pared so as to almit entrance of a solution and th'n phunged quickly into a small vial containing a watery solution of eosin. These vials were serurely tied to the shoot and heft suspenterl for two hours. At the end of that time, on cutting leaves from these shoots, eosin staining was fouml in the vasudar systems of all. On examining backwart towar, the tree, eosin was found as far hack as thirty centimeters. This experiment was repreated a number of times both at Erison and at Riverside and uniformly gave the same results, althongh much less markicl at the latter place. In every case the backward movenent of the easin solution was at its maximum during the aftrmoon.

cutting the ends of hranches in situ under a watery solution of eosin was tried at different times of clay and gave similar results. This experiment was performed at Edison, Riverside and Indio. At the latter place, with the temperature at $116^{\circ} \mathrm{F}$ and the humidity at 8\% the eosin solution traveled lackwart at the astonishing rate of $30 \mathrm{~cm}$. per minute at $6 \mathrm{P.M}$. Similar results were obtained using Eucalyptus rudis as material. In fact with long slenter poles of Euculyptus trreticornis at Elison, such a remarkably rapid backward flow of eosin was olserver ( $105 \mathrm{~cm}$. in one minute) in the afternoon as to compel the conclusion that after all, the force responsible for this movement under such conditions must be negative pressure pro- 


\section{1'L TE 13}

Fig. 1. Showing extent to which the leaves can draw on the water in the fruit. Both shoots were eut at the same time and hal aplroximately the same leaf area. All cuts were sealed with raseline. The fresh-appearing leaves on the sloot at the left have maintained themselves at the expense of water in the fruit. Note the lifference in reflection of light from the two fruits. See Experiment 1.

Fig. 2. Photograph illustrating an orange shoot so arrangerl as to be able to Iraw water from whe end and eosin solution through the pared apex of a snall fruit at the other. In spite of this double supply a large water rleficit occurred, and eosin was drawn back from the container on the right to the leaf next to the water container on the left. See Experiment 6 . 


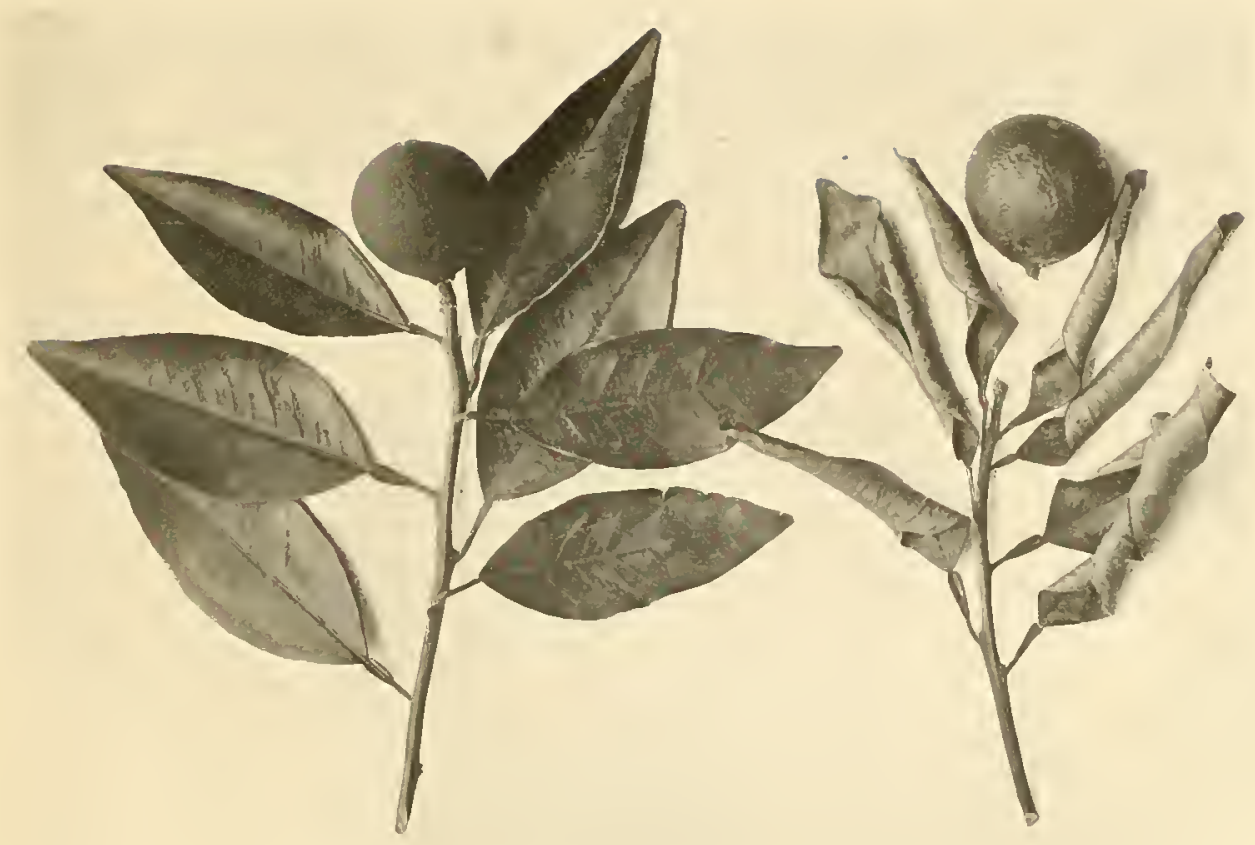

Fig. 1

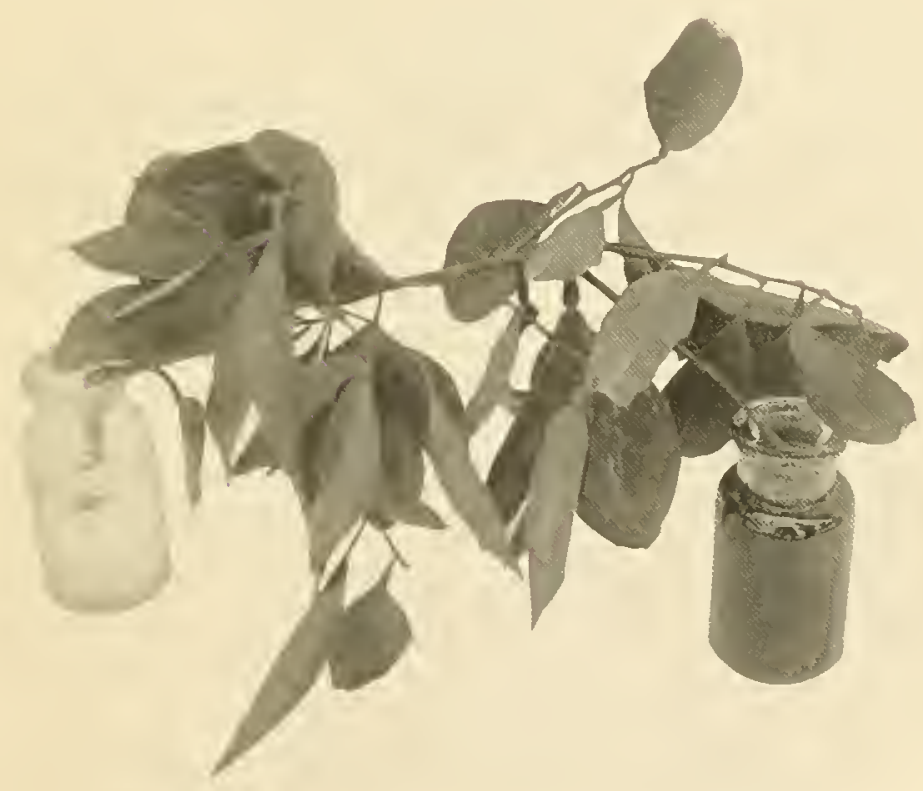

Fig. $\stackrel{3}{2}$ 



UNIVEESITY OF OATIFORNIA PUBLICATION\&-(Continued)

BOTANY.-W. A. Setchell, Editor. Price per Volume, \$3.50. Volumes I (pp. 418), II (pp. 360), III (pp. 400), and IV (pp. 397) completed. Volumes V, VI, and VII in progress.

Vol. 8. 1. Compositae of Sonthern Californla by Harvey Monroe Hall. Pp. 1. 302; plates 1-3, with a map. December, 1907

2. The Origin, Structure, and Function of the.Polar Caps in Snilacina amplexicaulis Nutt, by H. D. Donsmore. Pp. 303-350; plates 4-8. December, 1908

3. 4. (In ono cover.) The Value of Sodium to Plants by Reason of It: Protective Action. On the Effects of Certain Polsonous Gases on Plants. By W. J. V. Osterhout. Pp. 331-310, Juno, 1908

5. Contributions to the Knowledge of the California Specles of Crusta ceous Corallines, I, by Maurice Barstow Nichols. Pp. 341-348; plato 9. December, 1908

8. Contributions to the Knowledge of the California Species of Crustaceous Corallines. II, by Maurice Barstow Nichols. Pp. \$49-370; plates 10-13. April, 1909

7. Now Chlorophyceae from Califormia, by Nathaniel Iyou Gardner. Pp.

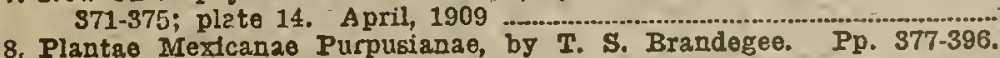
May, 1909 Inder, pp. $397-400$.

Vol. 4. 1. Studies in Ornamental Trees and Shrubs, by Harvey Monroe Hall. Pp. 1-74; plates 1-11; 15 text-figures. March, 1910

2. Gracllariophila, a New Parasite on Gracilaria confervoides, by Harriet I. Wilson. Pp. 75-81; plates 12-13. May, 1910

8. Plantae Mexdcanae Purpuslanae, II, by T. S. Brandegee. Pp. 85-95. May, 1910

4. Leuvenia, a New Genus of Flagellates, by N. I. Gardner. Pp. 97-108; plate 14. May, 1910 .

6. The Genus Sphaerosoma, by William Albert Setchell. Pp. 107-120; plate 15. May, 1910

6. Variations in Nuclear Extruston Among the Fucacea, by Nathaniel Iyon Gardner. Pp. 121-196; plates 16-17. August, 1910

7. The Nature of the Carpostomes in the Cystocarp of Ahnfeldita gigartinoides, by Ada Sara MeFadden. Pp. 137-142; plate 18. Fobruary, 1911

8. On a Colacodasya from Southern Callfornia, by Mabel Effe McFaddon. Pp. 143-150; plate 19. February, 1911.

9. Fructification of Macrocystis, bg Edna Juanita Hoffman. Pp. 151-158; plate 20. February, 1911

10. Erythrophyllum delesserioides J. Ag., by Wilfred Charles Twiss. Pp. 159-176; plates 21-24. March, 1911

11. Plantae Mexicanae Purpusianse, III, bJ T. S. Brandegee. Pp. 177-194. July, 1911

12. Now and Noteworthy Callfornia Plants, I, by Harvey Monroe Hall.

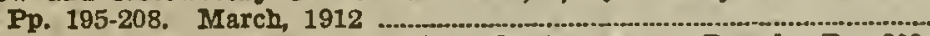

13. Dle Hydrophyllaceen der Sierra Nevada, by August Brand. Pp. 209. 227. March, 1912

14. Algae Novao et Minus Cognitao, I, bg William Albert Setchell. Pp. 229-268; plates 25-31. May, 1912

16. Plantáe Mexlcanae Purpustanae, IV, by Townsbend Stith Brandegeo. Pp. 269-281. June 26, 1912

18. Comparative Development of the Cystocarps of Antithamnion and Prionitis, by Iyman I. Daines. Pp. 283-302; plates 32-34. March, 1912

17. Fungus Galls of Cystoseira and Halidrys, by Lulu M. Este6. Pp. 305.316; plate 35. March, 1913

18. Now Fucaceae, by Nathaniel I. Tardner. Pp. 317-374; plates 36-63. April, 1913

19. Plantae Mexdcana Purpusianae, $\nabla$, by Townshend Stith Brandegee. Pp. \$75-388. June, 1913 Index, pp. 389-397.

Vol. 5. 1. Studies in Nicotiana I, by William A. Setchell. Pp. 1-86; plates 1-28. December, 1912

2. Quantitative Studies of Inheritance in Nicotiana Hybrids, by Thomas H. Goodspeed. Pp. 87-168; plates 29-34. December, 1912

3. Quantitative Studies of Inheritance in Nicotiana Eybrids II, by Thomas H. Goodspeed. - Pp. 169-188. January, 1913

4. On the Partlal Sterility of Nicotiana Hybrids made with $N$. Sylvestris as a Parent, by Thomas H. Goodspoed. Pp. 189-198. March, 1918.. 
ONIVEREITY OF CALIFORNIA PUBLICATIONB-(Continned)

5. Notes on the Germination of Tobacco Seed, by Thomas Harper Goodspeed. Pp. 199.222. May, 1913

6. Quantitative Studies of Inheritance in Nicotiana Hybrids, III, by. Thomas Harper Goodspeed. Fp. 223-231. April, 1915.

7. Notes on the Germination of Tobacco Seed, II, by Thomas Harper Goodspeed. Pp. 233-248. June, 1915

8. Parthenogenesis, Parthenocarpy, and Phenospermy in Nicotiana, by Thomas Harper Goodspeed. Pp. 249-272, plate 35. July, 1915

9. On the Partial Sterility of Nicotiana Hybrids made with $N$. sylvestris as a Parent, II, by T. II. Goodspeed and A. H. Ayres. Pp. 273-292, pl. 36. October, 1916

10. On the Partial Sterllity of Nicotiana Hybrids made with $N$. sylvestris as a Parent, III: An Account of the Mode of Floral Abscission in the $F_{1}$ Species Hybrids, by T. H. Goodspeed and J. N. Kendall. Pp. 293. 299. Niovember, 1916

11. The Nature of the $F_{1}$ Species Hybrids between Nicotiana sylvestris and Varieties of Nicotiana Tabacum, with Special Reference to the Con. ception of Reaction System Contrasts in Heredity, by T. F. Goodspeed and R. E. Olausen. Pp. 301-346, pls. 37-48. January, 1917

Voi. 6. 1. Parasitic Florideae, I, by William Albert Setchell. Pp. 1-34, plates 1-6. April, 1914

2. Phytomorula regularis, a Symmetrical Protophyte related to Coclastrum,

by Charles Atwood Kofoid Pp. 35-40, plate 7 April, $1914 \ldots \ldots . . . . . .$.
3. Variation in Oenothera ovata, by Katherine Layne Brandegee. Pp. 41 50, plates 8-9. June, 1914

4. Plantae Mexlcanae Purpusianae, VI, by Townshend Stith Brandegee. Pp. 51-77. August, 1914

5. The Scinaia Assemblage, by Wllliam A. Setchell." Pp. 79-152, plates 1016. October, 1914

6. Notes on Pacific Coast Algae, I; Pylaiella Postelsiae, n. sp, a New Typo in the Genus Pylaiella, by Carl skottsberg. Pp. 153-164, plates 17-19. May, 1915

7. New and Noteworthy Califoritan Plants, II, by Harvey Monroe Hall. Pp. 165-176, plate 20.: October, 1915

8. Plantae Mexicanae Purpusianae, VII, by T. S. Brandegee, Pp. 177-197. October, 1915

9. Floral Relations among the Galapagos Islands, by A. I. Kroeber, Pp. 199-220. March, 1916

10. The Comparative Histology of Certain Californian Boletaceae, by Harry S. Yates. Pp. 221-274, plates 21-25. February, 1916

11. A revision of the Tuberales of California, by Helen Margaret Gilkey. Pp. 275-356, plates 26-30. March, 1916

12. Species Novae vel Minus Cognitae, by T. S. Brandegee. Pp. 357-361. April, 1916

Vol 7. Notes on the Callfornlan Species of Trillium.

1. A Report of the General Results of Field and Garden Studies, 1911 1916, by Thomas Harper Goodspeed and Robert Percy Brandt. Pp. 1-24, pls. 1-4. October, 1916

2. The Nature and Occurrence of Undeveloped Flowers, by Thomas Harper Goodspeed and Robert Percy Brandt. Pp. 25-38, pls. 5-6. October, 1916

3. Seasonal Changes in Trillium Species with Special Reference to the Reproductive Tissues, by Robert Percy Brandt. Pp. 39-68, pls. 7-10. December, 1916

4. Teratological Variations of Trillium sessile var. giganteum, by Thomas Harper Goodspeed. Pp. 69-100, pls. 11-17. January, 1917

.25

.10

.15

.25

.20

.05

.45

.35

.05

.10

.25

.75

.10

10

.20

20

.50

.80

.05

AMERIOAN ARCHAEOLOGY AND E2HNOLOGY.-A.' I. Kroeber, Editor. Price per volume, $\$ 3.50$ (Voiume $I, \$ 4.25$ ). Volumes I-X completed. Volumes $X I$ and $X I I$ in progress.

GEOTOGY.-Bulletin of the Department of Geology. Andrew O. Lawson and John 0. Mezriam, Editors. Price per volume, \$3.50. Volumes I (pp. 428), II (pp. 450), III (pp. 475), IV (pp. 462), V (pp. 458), VI (pp. 454), VII (pp. 504), VIII (pp. 583), and IX (pp. 545) completed. Volume $\mathbf{X}$ in progress.

Other series in Classical Philology, Economics, Education, Egyptian Azchaeology, Engtneering, Entomology, Geography, Graeco-Roman Archaeology, History, Mathematics, Moder Philology, Pathology, Rhilosophy, Psychology, Pbysiology, Semitic Philology.

UNIVERSTTY OF CALIFORNIA CHRONICIE.-An offlal record of University llfe, issued quarterly, edited by a committee of the faculty. Price $\$ 1.00$ per year. Ourrent volume No. XVIX.

ADMUNISTRATIVE BULLETINS OF THE UNIVERSITY OF OALTFORNIA.-Edited b the Recorder of the Faculties. Includes the Register, the President's Report the Secretary's Report, and other official announcements. 